\title{
Author Correction: 150,000-year palaeoclimate record from northern Ethiopia supports early, multiple dispersals of modern humans from Africa
}

\author{
Henry F. Lamb ${ }^{1}{ }^{1}$, C. Richard Bates ${ }^{2}$, Charlotte L. Bryant ${ }^{3}$, Sarah J. Davies ${ }^{1}$, Dei G. Huws ${ }^{4}$, \\ Michael H. Marshall ${ }^{1,5}$, Helen M. Roberts $\mathbb{D}^{1}$ \& Harry Toland ${ }^{1}$ \\ Correction to: Scientific Reports https://doi.org/10.1038/s41598-018-19601-w, published online 18 January 2018
}

Harry Toland was omitted from the author list in the original version of this Article. This has been corrected in the PDF and HTML versions of the Article, and in the accompanying Supplementary Information file.

The Acknowledgements section now reads:

“This project was funded by grants from the UK Natural Environmental Research Council (NERC; grant nos NER/B/S/2002/00540 and NE/DO12996/1) and NERC Radiocarbon Facility support (NRCF010001 allocation number 1201.1006). We thank members of the Department of Earth Sciences at Addis Ababa University for scientific and logistical support, especially the late Mohammed Umer; Addis Zeleke of Addis Geosystems plc; and the Amhara Region Agricultural Research Institute. Data are archived at the UK National Geoscience Data Centre, http://www.bgs.ac.uk/services/ngdc/home.html."

The Author Contributions section now reads:

"H.F.L., C.R.B., S.J.D. and D.H. planned the project and undertook fieldwork in Ethiopia. M.H.M. undertook fieldwork and carried out XRF scans and laboratory analyses. H.M.R. determined luminescence dates and constructed the age model; C.B. carried out radiocarbon analyses. H.T. assisted with fieldwork and in the laboratory. All authors discussed the results and interpretation. H.F.L. wrote the manuscript with input from C.R.B., S.J.D., D.H. and H.M.R.”

(i) Open Access This article is licensed under a Creative Commons Attribution 4.0 International (c) License, which permits use, sharing, adaptation, distribution and reproduction in any medium or format, as long as you give appropriate credit to the original author(s) and the source, provide a link to the Creative Commons license, and indicate if changes were made. The images or other third party material in this article are included in the article's Creative Commons license, unless indicated otherwise in a credit line to the material. If material is not included in the article's Creative Commons license and your intended use is not permitted by statutory regulation or exceeds the permitted use, you will need to obtain permission directly from the copyright holder. To view a copy of this license, visit http://creativecommons.org/licenses/by/4.0/.

(C) The Author(s) 2018

${ }^{1}$ Department of Geography and Earth Sciences, Aberystwyth University, Aberystwyth, SY23 3DB, UK. ${ }^{2}$ Department of Earth and Environmental Sciences, Irvine Building, University of St Andrews, St Andrews, Fife, KY16 9AL, UK. ${ }^{3}$ NERC Radiocarbon Facility, Scottish Enterprise Technology Park, Rankine Avenue, East Kilbride, G75 0OF, UK.

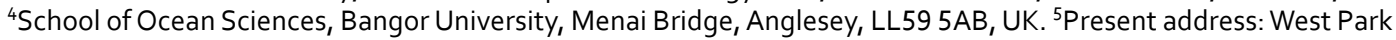
School, West Road, Spondon, Derby, DE21 7BT, UK. Correspondence and requests for materials should be addressed to H.F.L. (email: hfl@aber.ac.uk) 